\title{
Analisis Kebutuhan Bahan Ajar Bahasa Inggris Berbasis Local Learning Pada Siswa Sekolah Dasar
}

\author{
Oktariyani* dan Rani Puspa Juwita \\ Pendidikan Bahasa Inggris, Universitas Nahdlatul Ulama Lampung, Indonesia \\ *oktariyani.yani@gmail.com
}

\begin{abstract}
Abstrak
Artikel ini bertujuan untuk mengemukakan hasil analisis kebutuhan bahan ajar Bahasa Inggris Sekolah Dasar (SD) berbasis local learning. Data dalam artikel ini dikumpulkan melalui penyebaran angket yang diisi oleh dua orang guru Bahasa Inggris dan 26 orang siswa kelas III SD Negeri 09 Duren Tiga Jakarta Selatan semester ganjil, tahun ajaran 2018/2019, lalu dianalisis dengan menggunakan analisis deskriptif. Objek kajian dalam artikel ini mencakup: 1) kesesuain KI dan KD, 2) bahan ajar yang digunakan guru, dan 3) kebutuhan guru dan siswa terkait bahan ajar berbasis local learning. Hasil studi menunjukkan bahwa: 1) Semua materi pada bahan ajar sudah sesuai dengan KI dan KD 2) Guru dan siswa menggunakan bahan lain selain buku dari sekolah untuk membantu dalam memahami suatu materi; dan 3) Guru dan siswa membutuhkan bahan ajar berbasis local learning yang dapat digunakan untuk mempelajari materi noun dan adjective. Dengan demikian, dapat dipahami bahwa bahan ajar berbasis local learning diperlukan.
\end{abstract}

Kata kunci: analisis, bahan ajar, bahasa inggris, local learning .

Diterima: 29 Desember 2019

\section{PENDAHULUAN}

Bahan ajar adalah pesan yang perlu disampaikan oleh penyelenggara pendidikan kepada peserta didik Syafii (2017). Dengan kata lain bahan ajar sering disebut sebagai materi pelajaran. Dalam konteks lain bahan ajar merupakan isi pelajaran (subject content). Oleh karena itu bahan ajar sesungguhnya merupakan bentuk terurai dari isi kurikulum dapat disampaikan secara sangat terinci, jelas dengan penuh ilustrasi, atau sebaliknya dibuat seperlunya saja (Syafii, 2016). Hal tersebut sangat tergantung bagaimana proses pembelajaran itu dikemas.

Seorang guru harus pandai untuk menciptakan suasana belajar yang kondusif di lingkungan sekolah. Suasana belajar yang kondusif dapat diwujudkan dengan pemilihan metode dan bahan ajar yang tepat (Andani \& Yulian, 2018). Sementara itu untuk menyampaikan bahan ajar tersebut membutuhkan sebuah media sehingga penyampaianya mudah diserap oleh si penerima. Media tersebut di sebut dengan media pembelajaran. Media pembelajaran bagi guru adalah sebuah alat atau cara untuk memberikan materi pelajaran kepada siswa sehingga siswa dapat memahami materi dengan mudah. Karena, salah satu fungsi utama media pembelajaran adalah sebagai alat bantu mengajar yang turut mempengaruhi iklim, kondisi, dan lingkungan belajar yang ditata dan diciptakan oleh guru (Arsyad, 2010).

Media pembelajaran dapat berupa media audio, media visual, dan gabungan antara kedua media audio dan visual. Media audio yaitu media yang hanya mengandalkan kemampuan suara saja, seperti radio, kaset, dan piringan hitam. Media visual yaitu media yang hanya mengandalkan indra penglihatan (Nugrahani, 
2007). Media visual ini ada yang menampilkan gambar diam seperti film strip (film rangkai), slides (film bingkai), foto, gambar atau lukisan, cetakan. Ada pula media visual yang menampilkan gambar atau simbol yang bergerak seperti film bisu, dan film kartun. Media audio visual adalah media yang mempunyai unsur suara dan unsur gambar (Hastuti \& Budianti, 2014). Jenis media ini mempunyai kemampuan yang lebih baik, karena meliputi kedua jenis media yang pertama dan kedua.

Mewujudkan manusia yang berilmu, berbudaya, bertakwa serta mampu menghadapi tantangan diera globalisasi Salah satu faktor utamanya adalah kemampuan guru menggunakan media dan metode dalam proses pembelajaran (Alwi, 2017). Implementasi media pembelajaran menuntut pemahaman guru secara komprehensif tentang konsep, penyusunan, serta ketersediaan sarana dan prasarana. Guru memiliki peranan penting dalam mengimplementasikan media pembelajaran, salah satu keberhasilan sebuah media pembelajaran bergantung pada aktivitas dan kreativitas guru dalam mengembangkan dan merealisasikannya.

Berdasarkan hasil observasi yang dilakukan peneliti di tiga sekolah yakni; SD Negeri 09 Pagi Duren Tiga, SD IT Al-Muzzamil, dan di SD Negeri. Diperoleh bahwa proses pembelajaran di lapangan, belum dilaksanakan sebagaimana yang diharapkan. Terutama untuk di sekolah-sekolah negeri. Mata pelajaran bahasa Inggris tidak semua sekolah ada di setiap tahun. Menurut keterangan guru dan kepala sekolah di SD tersebut pada tahun 2018 mata pelajaran bahasa Inggris di adakan dalam bentuk muatan Lokal. Pada tahun 2019 siswa tidak menerima mata pelajaran bahasa Inggris lagi, karena sekolah memilih mata pelajaran Kebudayaan Jakarta. Hal ini tentu saja menjadi hambatan dan tantangan besar bagi para guru bahasa Inggris di SD. siswa akan ketinggalan materi yang seharusnya sudah jauh diberikan. Sementara untuk SD Swasta di Jakarta yang peneliti ambil sampel yaitu SD IT Al-Muzzamil Bekasi, sekolah ini setiap tahun ada mata pelajaran bahasa Inggris dan seminggu sekali dilaksanakan. Dengan demikian ada kesenjangan yang terjadi antara SD Negeri dengan SD Swasta, anak-anak yang bersekolah di SD Negeri pengetahuan dan kemampuan bahasa Inggrisnya jauh tertinggal di bandingkan dengan anak-anak yang sekolah di Swasta. Apalagi jika siswa di sekolah negeri tidak mendapatkan materi bahasa Inggris dengan cara belajar di luar sekolah yaitu kursus atau les di rumah.

Proses pembelajaran bahasa Inggris di SD masih mengalami kendala yaitu pembelajaran masih menggunakan pendekatan teacher centered atau berpusat pada peranan guru. Dalam praktek pembelajaran yang dilaksanakan guru seringkali didapati gejala bahwa proses pembelajaran berjalan monoton, situasi kelas bersifat pasif dan verbalitas, yaitu siswa hanya diberi jalan dan menerima, dan guru melaksanakan pengajaran dengan penuturan (verbal) semata-mata. Jarang dijumpai keaktifan belajar yang lebih jauh seperti berdiskusi, atau melakukan penemuan. Selain itu masih banyak guru yang belum tahu bagaimana cara memanfaatkan media pembelajaran. Hal ini tentu saja disebabkan karena guru masih mengalami demam teknologi, yang diartikan bahwa banyak guru yang masih takut dan belum terampil dalam menggunakan alat-alat teknologi sebagai media pembelajaran.

Guru juga menyatakan bahwa sumber belajar yang dibutuhkan untuk dikembangkan dan dapat dijadikan sumber belajar mandiri untuk siswa adalah media pembelajaran yang berbentuk video animasi permainan tradisional. Namun di sekolah-sekolah yang diobservasi baik guru maupun pihak pengembang lain belum pernah melakukan pengembangan media pembelajaran berbasis local 
learning. Oleh karena itu, media pembelajaran yang dapat mendemonstrasikan materi pembelajaran khususnya pada materi noun dan adjective bertujuan untuk mempermudah siswa dalam memahami kemampuan bahasa Inggris dengan baik. Local learning itu sendiri adalah sebuah pembelajaran yang melibatkan kebiaasaan, adat istidat, kebudayaan atau seni dari masyarakat setempat yang memiliki nilainilai budaya yang khas. Misalnya permainan tradisional, lagu daerah, tari daerah, cerita rakyat dan lain-lain. Namun dalam hal ini peneliti hanya focus pada permainan tradisionalnya.

Peneliti mengambil subjek siswa di Ibu Kota Jakarta karena peneliti ingin mengetahui bagaimana respon siswa-siswa tersebut terhadap permainan tradisional. Di jaman yang serba teknologi ini siswa-siswa tersebut sudah sangat jarang di temui yang bermain permainan tradisional (Winarsih, 2017), apalagi untuk siswa yang berada di Ibu Kota seperti Jakarta. Anak-anak di yang tinggal di Ibu kota cenderung bersikap personal, bersosialisasi hanya ketika berada di sekolah atau di tempat kursus. Jika sudah tiba di rumah mereka bermain hanya dengan handphone mereka. Jarang sekali ditemui anak-anak seumuran SD berada di luar rumah, di halaman rumah, atau di lapangan bola, dan di lapangan basket yang sedang bermain permainan tradsional bersama teman-temanya.

Anak-anak sangat tertarik untuk memainkan game yang ada di handphone. Baik itu game online maupun offline Oktariyani \& Juwita (2019). Game yang biasa dimainkan anak-anak biasanya adalah game-game yang berkiblat kepada budaya luar. Jenis-jenis game yang anak-anak bisa kapan saja men-downloud dan memainkannya antara lain, Papa's Suhiria, Bob, Sang Pencuri, Papa's Pancakeria, Fidget Spinner, Jungle Jiggy, Drum Session, 3 Panda in Brasil, We Dancing Online, Making Smile, dan lain sebagainya. Bahkan ada beberapa jenis game yang tidak boleh dimainkan oleh anak-anak, karena menyajikan tentang kekerasan, pencurian dan seksual. Seperti game dengan judul Alpha Protocol, Far Cry 3, Blood Dragon, the witcher 2, mass Effect 2, Dragon Age, Metro Last Light dan lain-lain. Oleh karena itu dalam hal ini peneliti melakukan sebuah analisis kebutuhan terhadap media pembelajaran Bahasa Inggris Berbasis Local Learning pada Siwa SD. Media pembelajaran ini nantinya akan berbentuk video animasi permainan tradisional yang dikemas sedemikian rupa dalam bahasa Inggris. Sehingga pembelajaran bahasa Inggris di SD bisa digunakan oleh semua guru bahasa Inggris di SD dan proses pembelajaran pun menjadi lebih menarik dan menyenangkan.

Berikut gambar rancangan prosedur pengembangan media yang akan di dikembangkan.

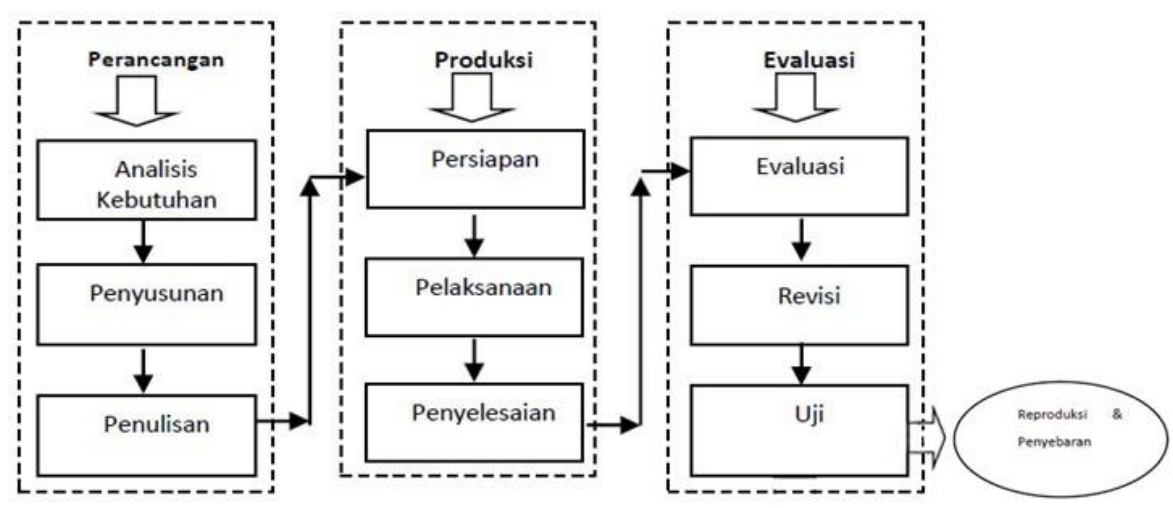

Gambar 1. Prosedur Pengembangan Media 


\section{METODE PENELITIAN}

Penelitian ini merupakan penelitian awal yang termasuk di dalam tahap pra pengembangan dalam prosedur penelitian dan pengembangan (R\&D) oleh (Sugiyono, 2010). Namun pada artikel ini, tahapan penilitian hanya dibatasi pada tahap analisis kebutuhan saja. Sejalan dengan hal tersebut, artikel ini digunakan untuk menganalisis kebutuhan bahan ajar bahasa Inggris berbasis local learning untuk siswa SD Negeri 09 Pagi Duren Tiga Kelas III.

Subjek dalam artikel ini adalah siswa dan guru SD negeri 09 Pagi Duren Tiga. Analisis kebutuhan ini dilaksanakan pada 04 Juni 2019 dari 2 (dua) orang guru bahasa Inggris dan 26 (dua puluh enam) siswa kelas III SD Negeri 09 pagi Duren Tiga Jakarta Selatan. Objek kajian dalam artikel ini mencakup: 1) kesesuain KI dan $\mathrm{KD}, 2$ ) bahan ajar yang digunakan guru, 3) kebutuhan guru dan siswa terkait bahan ajar berbasis local learning, dan 4) kesulitan siswa dalam mempelajari materi noun dan adjective. Pengumpulan data dilakukan dengan menggunakan angket yang peneliti sebar ke sekolah secara langsung. Data diaanalisis secara deskriptif.

\section{HASIL DAN PEMBAHASAN}

Ada beberapa pertanyaan untuk guru dan siswa yang peneliti tanyakan melalui angket, pertanyaan untuk guru terdiri dari 6 pertanyaan dan pertanyaan untuk oleh siswa terdiri 11 pertanyaan. Hasil dari pengisian angket guru, yaitu: 1) $70 \%$ guru memiliki buku teks atau buku pegangan lain untuk belajar materi noun dan adjective; 2) $100 \%$ bahan ajar yang digunakan sudah sesuai dengan $\mathrm{KI}$ dan $\mathrm{KD}$; 3) $100 \%$ guru mencari bahan lain selain buku dari sekolah untuk membantu dalam memahami suatu materi, misalnya melalui bahan ajar atau internet; 4) 30\% guru menggunakan bahan ajar khusus untuk membelajarkan materi noun dan adjective; 5) $100 \%$ guru membutuhkan bahan ajar berbasis local learning yang dapat digunakan untuk mempelajari materi noun dan adjective agar lebih mudah dan menarik; dan 6) 100\% guru setuju apabila dikembangkan bahan ajar berbasis local learning untuk membelajarkan materi noun dan adjective sehingga materi tersebut mudah menarik dipahami. Persentase di atas dimuat dalam Tabel 1.

Tabel 1. Hasil Angket kepada Guru

\begin{tabular}{lc}
\hline \multicolumn{1}{c}{ Pernyataan } & $(\%)$ \\
\hline Guru memiliki buku teks atau buku pegangan lain untuk belajar & 70 \\
\hline $\begin{array}{l}\text { Bahan ajar yang digunakan sudah sesuai dengan kompetensi inti dan } \\
\text { kompetensi dasar }\end{array}$ & 100 \\
\hline $\begin{array}{l}\text { Guru mencari bahan lain selain buku dari sekolah untuk membantu dalam } \\
\text { memahami suatu materi, misalnya melalui bahan ajar atau internete }\end{array}$ & 100 \\
\hline Guru menggunakan bahan ajar khusus untuk membelajarkan bahasa inggris & 30 \\
\hline Guru membutuhkan bahan ajar berbasis local learning & 100 \\
\hline Guru setuju apabila dikembangkan bahan ajar berbasis local learning. & 100 \\
\hline
\end{tabular}

Sementara hasil wawancara peneliti kepada siswa yaitu; 1) 84\% siswa memiliki buku teks atau buku pegangan lain untuk belajar materi noun dan dan adjective; 2) $70 \%$ siswa mencari bahan lain selain buku dari sekolah untuk membantu dalam 
memahami suatu materi; 3) 90\% siswa mengalami kesulitan mempelajari materi noun dan adjective dari buku teks tersebut; 4) $90 \%$ siswa diberi bahan ajar agar lebih mudah memahami materi noun dan adjective; 5) $60 \%$ siswa antusias mengikuti pembelajaran pada materi noun dan adjective; 6) $75 \%$ siswa menganggap materi noun dan adjective sulit dipahami; 7) 35\% siswa mengalami kesulitan memahami materi noun dan adjective melalui bahan ajar dan metode yang diterapkan guru; 8) 80\% siswa membutuhkan bahan ajar berbasis local learning yang dapat digunakan untuk mempelajari materi noun dan adjective agar lebih mudah dan menarik; dan 9) 95\% siswa setuju apabila dikembangkan bahan ajar berbasis local learning untuk mengajarkan materi noun dan adjective sehingga materi tersebut mudah dipahami. Persentase tersebut dimuat dalam Tabel 2.

Tabel 2. Persentase Hasil Angket kepada Siswa

\begin{tabular}{lc}
\hline \multicolumn{1}{c}{ Pernyataan } & $\%$ \\
\hline Siswa setuju & 95 \\
\hline Siswa butuh bahasa ajar & 80 \\
\hline Siswa sulit paham materi Bahasa Inggris & 35 \\
\hline Siswa menganggap bahasa ingris sulit dipahami & 75 \\
\hline Siswa antusias mengikuti pembelajaran bahasa inggris & 60 \\
\hline Siswa diberi bahan ajar agar lebih mudah memahami bahasa inggris & 90 \\
\hline $\begin{array}{l}\text { Siswa mengalami kesulitan mempelajari bahasa inggris dari buku teks } \\
\text { tersebut }\end{array}$ & 90 \\
\hline $\begin{array}{l}\text { Siswa mencari bahan lain selain buku dari sekolah untuk membantu } \\
\text { dalam memahami suatu materi }\end{array}$ & 70 \\
\hline $\begin{array}{l}\text { Siswa memiliki buku teks atau buku pegangan lain untuk belajar materi } \\
\text { bahasa Inggris }\end{array}$ & 84 \\
\hline
\end{tabular}

Berdasarkan hasil rangkuman penyebaran angket guru maupun siswa yang dimuat dalam Tabel 1 dan Tabel 2, siswa dan guru setuju untuk menggunakan bahan ajar berbasis local learning dimana bahan ajar tersebut dapat dimanfaatkan secara individu dan kelompok dengan melibatkan siswa dan guru sebagai fasilitator. Hal ini dikarenakan pada bahan ajar berbasis local learning pembelajaran yang menekankan kemandirian seluruh siswa dalam memahami isi materi yang diberikan guru agar siswa dapat dengan mudah memahami isi materi yang diberikan guru, kemudian akan terwujudnya berbagai macam pemikiran dan berbagai pemahaman terhadap siswa. Oleh karena itu, keberadaan bahan ajar pada proses pembelajaran bahasa Inggris sangat penting.

Namun masih ada siswa mengatakan bahwa bahan ajar yang digunakan memberikanmasih sulit mereka pahami dalam materi noun dan adjective. Hal ini membuktikan bahwa bahan ajar yang ada belum mampu menampilkan komponen dari setiap materi dengan mengimplikasikanya dengan kehidupan sehari-hari. Dengan demikian, masih perlu dikembangkan bahan ajar bahasa Inggris berbasis local learning.

\section{KESIMPULAN}

Sejalan dengan tujuan penelitian yaitu untuk menganalisis kebutuhan bahan ajar berbasis local learning. Hasil analisis angket analisis kebutuhan siswa SD dapat di 
identifikasi bahwa guru dan siswa SD Negeri 09 pagi Duren Tiga Jakarta Selatan sangat setuju dan mendukung adanya pembuatan dan pengembangan bahan ajar berbasis local learning pada mata pelajaran Bahasa Inggris. Berdasarkan temuantemuan yang diperoleh dari hasil analisis, peneliti menemukan perlunya dilakukan perbaikan dan peningkatan kualitas pembelajaran Bahasa Inggris di SD Negeri 09 Duren Tiga. Salah satu hal yang perlu dilakukan adalah peningkatan kualitas kemampuan guru dalam merancang dan melaksanakan kegiatan pembelajaran Bahasa Inggris serta pengadaan dan penambahan bahan ajar yang dapat meningkatkan minat dan motivasi siswa. Hal ini dapat dilakukan dengan memberi pembekalan pengetahuan dan kemampuan kepada guru dalam merancang dan melaksanakan kegiatan dalam pembelajaran Bahasa Inggris, sekaligus mengembangkan bahan ajar seperti bahan ajar berbasis local learning.

Temuan dalam artikel ini secara praktis dapat ditindaklanjuti oleh peneliti serta pihak sekolah dalam membenahi bahan ajar yang digunakan oleh guru . Guru bahasa Inggris juga harus terus menggali potensi dan kebutuhan lokal yang layak diintegrasikan dalam pembelajaran bahasa Inggris, sehingga pembelajaran menjadi bermakna, menyenangkan, dan berkelanjutan. Tanpa adanya perubahan sikap di kalangan guru-guru, implementasi bahan ajar berbasis local learning di tingkat kelas akan mengalami kegagalan.

\section{UCAPAN TERIMA KASIH}

Tim peneliti menyampaikan terima kasih yang sebesar-besarnya kepada Direktorat Riset dan Pengabdian Masyarakat, Direktorat Jenderal Penguatan Riset dan Pengembangan, Kementerian Riset, Teknologi, dan Pendidikan Tinggi yang telah membiayai penelitian ini dari dana hibah Penelitian Dosen Pemula (PDP) untuk pelaksanaan tahun anggaran 2019. Semoga semua pihak yang telah membantu tim peneliti mendapatkan keberkahan dari Yang Maha Kuasa.

\section{REFERENSI}

Alwi, S. (2017). Problematika Guru dalam Pengembangan Media Pembelajaran. ITQAN: Jurnal Ilmu-Ilmu Kependidikan, 8(2), 145-167.

Andani, D. T., \& Yulian, M. (2018). Pengembangan Bahan Ajar Electronic Book Menggunakan Software Kvisoft Flipbook Pada Materi Hukum Dasar Kimia di SMA Negeri 1 Panton Reu Aceh Barat. Jurnal IPA \& Pembelajaran IPA, 2(1), $1-6$.

Arsyad, A. (2010). Media Pengajaran. Jakarta: Raja Grafindo Persada.

Hastuti, A., \& Budianti, Y. (2014). Pengaruh Penggunaan Media Audio Visual Terhadap Hasil Belajar Siswa Pada Mata Pelajaran IPA Kelas II SDN Bantargebang II Kota Bekasi. Pedagogik (Jurnal Pendidikan Sekolah Dasar), 2(2), 33-38.

Nugrahani, R. (2007). Media pembelajaran berbasis visual berbentuk permainan ular tangga untuk meningkatkan kualitas belajar mengajar di sekolah dasar. Lembaran Ilmu Kependidikan, 36(1), 35-44.

Oktariyani, O., \& Juwita, R. P. (2019). Pengembangan Bahan Ajar Bahasa Inggris Berbasis Local Learning Pada Siswa Sekolah Dasar. Syntax Literate; Jurnal Ilmiah Indonesia, 4(10), 103-115. 
Oktariyani, O. \& Juwita, R. P. (2019). Persepsi Siswa Terhadap Media Pembelajaran Bahasa Inggris Berbasis Local Learning. BaJET (Baturaja Journal of Education Technology), 3(1), 149-151.

Sugiyono. (2010). Metode Penelitian Kuantitatif, Kualitatif dan R\&D. Bandung: Alphabeta.

Syafii, S. (2016). Pengembangan Bahan Ajar Seni Rupa dalam Konteks Pengembangan Profesi Guru. Imajinasi: Jurnal Seni, 10(2), 99-106.

Syafii, S. (2017). Pengembangan Bahan Ajar Ornamen Berbasis Candi di Jawa Tengah: Studi Identifikasi Candi Gedongsanga. Imajinasi: Jurnal Seni, 11(2), 117-124.

Winarsih, E. (2017). Permainan Tradisional "Engkling" untuk Meningkatkan Keterampilan Berbahasa, Interaksi Sosial, dan Sarana Pendidikan Anti Korupsi pada Siswa Sekolah Dasar di Kota Madiun. Widyabastra: Jurnal Ilmiah Pembelajaran Bahasa dan Sastra Indonesia, 1(2), 1-18. 